\title{
ISLAM DAN POLITIK \\ (Telaah atas Pemikiran Politik Kontemporer di Indonesia)
}

\section{Usman}

Fakultas Syariah dan Hukum Universitas Islam Negeri (UIN) Alauddin Makassar

\begin{abstract}
This paper deals with the study of one aspect of political thought in Indonesia. The principal issue is how the synthesis between religion and state in Islamic political thought, especially if the issue is seen from the context of Indonesianness. This problem is seen through a substantive approach and is discussed using content analysis.

From the literature review related to the political thinking of the figures it is concluded that religion and state are complementary and integralistic, in which religion becomes the spirit of the state, or to distinguish secular political thought in the West, the Indonesian political thinking is in a closer spectrum to Central axis or "middle way". While secular thought far enough away from the axis or middle way.

The dynamics of political thought in Indonesia do not physically adopt the basic assumptions on modern politics that are trand in the West but adopt from religious and cultural values encapsulated in Pancasila democracy. And therefore the state of Indonesia is neither a religious state nor a secular state, but a country in which religious values can live and thrive.
\end{abstract}

Keywords:

Islam, Politics, Contemporary

\begin{abstract}
Abstrak
Tulisan ini berkaitan dengan studi salah satu aspek dari pemikiran politik di Indonesia. Pokok permaslahan adalah bagaimana sintesis antara agama dan negara dalam pemikiran politk Islam, khususnya jika masalah ini dilihat dari konteks keindonesiaan. Masalah ini dilihat melalui pendekatan substantive dan dibahas dengan menggunakan content analysis.

Dari kajian literatur yang berkaitan dengan pemikiran politik tokohtokoh tersebut disimpulkan bahwa agama dan negara berhubungan secara komplementer dan integralistik, di mana agama menjadi roh negara, atau untuk membedakan pemikiran politik sekuler di Barat, maka pemikiran politik Indonesia berada pada spectrum yang lebih dekat dengan poros tengah atau "jalan tengah". Sedangkan
\end{abstract}


pemikiran sekuler cukup jauh dari poros atau jalan tengah.

Dinamika pemikiran politik di Indonesia tidaklah mengadopsi secara dokmatis asumsi-asumsi dasar pada perpolitikan modern yang menjadi trand di Barat tetapi mengadopsi dari nilai-nilai agama dan budaya yang terangkum dalam demokrasi pancasila. Dan oleh karena itu negara Indonesia bukanlah negara agama dan bukan pula negara sekuler, tetapi negara yang di dalamnya nilai-nilai agama bisa hidup dan berkembang.

Kata Kunci:

Islam, Politik, Kontemporer

\section{Pendahuluan}

erbincangan mengenai Islam dan politik atau agama dan negara memang
merupakan tema yang cukup menarik dan tak pernah basi untuk dibicarakan,
terutama setelah berkembangnya pemikiran politik sekular di dunia Islam termasuk di Indonesia. Perbincangan ini semakin mengemuka setelah penghapusan sistem kekhilafahan Turki Usmani oleh Mustafa Kemal al-Tattur pada tanggal 3 Maret 1924 dan diikuti dengan pencabutan Islam sebagai agama resmi negara serta penghapusan syari'at sebagai sumber hukum tertinggi negara.

Pemisahan agama dan negara (sekularisme) yang dilakoni Mustafa Kemal di Istambul merupakan sebuah perwujudan atas keinginan yang kuat untuk mengikuti dan mengadopsi pemikiran politik sekuler dari Barat dengan grand theory utamanya Max Weber. Sekularisme menjadi sesuatu yang dianggap baik oleh Barat karena secara histories ia terlahir dari perlawanan atas kejumudan pemikiran gereja pada abad pertengahan.

Di Indonesia, agama dan negara masih bersifat broblematis. Persoalan ini berpusat dan berakar pada bagaimana "menghadirkan" peran Islam dalam lingkup negara bangsa atau netion state. Ketika konstituante berupaya menyusun UUD yang baru, persoalan pilihan muncul: Pancasila atau Islam. Dan tarik menarik kepentingan politik yang demikian kuat dari golongan nasionalis sekuler dan nasionalis Islam tersebut, Akhirnya terjadilah kompromi politik dengan dikeluarkannya Dekrit Presiden yang menetapkan kembali ke UUD 1945. Begitupun ketika masa Orde Baru, Islam - terutama di masa-masa awal Orde Baru - dalam taraf tertentu, identik dengan ekstrim kanan, oposisi, anti-Pancasila, dan lain-lain sejenisnya. Kesan seperti ini muncul lagi, di masa Orde Kabinet Kerja, Jokowidodo sekarang ini.

Tesis di atas merupakan sebuah realitas emperis yang menjelaskan bahwa terdapat ketidak mampuan untuk mendialogkan visi sekuler dengan visi yang menginginkan warna agama dalam dasar negara sehingga negara dalam realitas politik terkadang melakukan penyimpangan dari etika dan moralitas agama.

Perkembangan mutakhir politik Indonesia menunjukkan bahwa agama merupakan suatu institusi politik yang paling penting dalam sistem pancasila. 
Sebab, dari agamalah para politisi mencoba memusatkan perhatian dalam pengertian mencari legitimasi mereka, baik secara langsung ataupun tidak. Agama dipergunakan sebagai sumber legitimasi bagi ketajaman-ketajaman moral dan keputusan-keputusan terhadap rakyat, yang merupakan basis dari masyarakat Indonesia.

Untuk mengetahui lebih jauh mengenai Islam dan politik atau agama dan negara dalam pemikiran politk Islam, khususnya jika masalah ini dilihat dari konteks keindonesiaan, maka dirasa perlu dikaji pandangan dan sikap-sikap politik atau pemikiran politik umat Islam terkemuka di Indonesia. Pandangan mereka dianggap sebagai representasi pemikiran dan mengikat dalam berbagai masalah, tidak hanya menyangkut masalah keagamaan tetapi juga dalam masalah-masalah lain.

\section{Islam dan Politik}

Telah terjadi polarisasi pemikiran politik dalam memandang Islam dan politik atau agama dan negara. Secara umum, terdapat tiga polarisasi pemikiran yang berkembang disekitar wacana tersebut di Indonesia, yaitu (1) pemikiran yang menghendaki keterpisahan agama dari sistem ketatanegaraan atau sekularisme; (2) wacana yang melihat agama dan negara bersifat komplementer; dan (3) wacana yang bercorak integralistik. ${ }^{1}$ Sebelum ketiga arus utama di atas dikemukakan, perlu diuraikan secara singkat mengenai latar belakang konseptual tentang agama. Karena konsepsi dan definisi membawa implikasi pada perbedaan wacana tentang agama dan negara. Konsepsi yang dimaksud adalah konsep agama yang berisi (1) ajaran moralitas, (2) pranata sosial politik dan hukum, bahkan mungkin (3) doktrin atau ajaran tentang metode hidup bidang ekonomi, dan juga doktrin tentang kehidupan politik.

Adapun ke tiga macam wacana mengenai agama dan negara yang dikemukakan di atas, yakni: pertama, pola pemisahan. Dilihat dari segi legitamsi kekuasaan, bahwa kekuasaan yang diabsahkan secara agama dinilai tidak sesuai lagi dengan etika politik suatu negara modern. Karena, kelemahan utama ligitimasi jenis ini terletak pada inti paham tentang kekuasaan agama, yaitu bahwa "hakikat kekuasaan tersebut berasal dari alam gaib atau Ilahi. ${ }^{2}$

Paham ini tidak menuntut legitamsi etis, dan legitimasi moral yang datang dari agama. ${ }^{3}$ Muhammad Hari Zamharir yang mengutip pendapat Suseno mengatakan bahwa dalam zaman sekarang ini, kebudayaan modern menolak keyakinan agama sebagai sumber kekuatan kehidupan nyata. Lebih lanjut Ia mengatakan, "Kekusaan politik dilihat sebagai realitas yang menusiawi, tanpa kekeramatan apa pun". ${ }^{4}$

\footnotetext{
${ }^{1}$ Lihat Muhammad, Hari Zamharir, Op. Cit., h. 74

${ }^{2}$ Lihat Lihat Ibid., 77 dan lihat pula Frans Magnis-Suseno, Etika Politik Prinsip-prinsip Moral Dasar Kenegaraan Modern (Jakarta: Gramedia, 1988), h. 34

${ }^{3}$ Lihat Ibid., dan lihat pula Suseno, Ibid., h. 32

${ }^{4}$ Lihat Ibid., h. 78
} 
Pola pemisahan agama dengan negara ini, menolak eksistensi "negara agama", juga kaitan hukum keagamaan. Negara tidak mungkin dikuasai oleh agama pada umumnya, dan oleh karena itu agama tidak mempengaruhi penyelenggaraan negara. Dan tidak mungkin negara diagamakan. Pandangan ini mencoba memisahkan antara urusan agama dan urusan negara.

Pandangan serupa ini juga datang dari pemikir politik sekular yang mengajukan pemisahan antara agama dan negara dalam arti menolak pendasaran negara kepada Islam, atau paling tidak menolak determinasi Islam akan bentuk tertentu dari pada negara. Salah seorang tokoh yang terkenal membawa pandangan ini adalah Ali Abd al-Raziq. Issu sentral yang diajukan adalah bahwa Islam tidak mempunyai kaitan sedikit pun dengan sistem pemerintahan, termasuk sistem pemerintahan kekhilafahan al-khulafa' al-rasyidun, bukan sebuah sistem politik keagamaan atau keislaman, tetapi sebuah sistem yang bersifat duniawi. ${ }^{5}$

Wacana kedua, adalah hubungan agama dan negara bersifat komplementer. Konsepsi "naionalisme Islam" Soekarno, mungkin contoh terbaik di Indonesia. Dengan pendektan sejarah, Soekarno yang menghendaki pemisahan agama Islam dari negara, dengan argumen: (1) penyatuan itu bertentangan dengan prinsip demokrasi; (2) hal itu dimungkinkan oleh watak hukum Islam yang lentur; dan (3) tidak ada konsensus ahli agama tentang bersatunya agama dan politik.

Meskipun Soekarno mengemukakan demikian, namun beliau tetap memberi peluang bagi umat Islam untuk berjuang melalui jalan politik, yakni berjuang di parlemen, dan jika menguasai kursi di parlemen, dapat menentukan kebijakan dan hukum-hukum negara. Jika proses konstitusional ini dapat dilalui umat Islam, maka persatuan agama dan negara adalah sah. Ini berarti bahwa meskipun Soekarno memisahkan Islam dari negara, namun pandangan ini tidak mendasar, karena sesungguhnya pandangan beliau bersifat "lunak", seperti dapat dilihat dari pernyataannya bahwa "Ini bukan berarti penghapusan aturan-aturan Islam. karena peraturan itu bisa dimasukkan ke dalam undang-undang dan peraturan dari negara, asal sebagian besar dari wakil-wakil rakyat di dalam perwakilan itu terdiri dari wakil-wakil Islam. ${ }^{6}$ Pandangan Soekarno ini, dalam penilaian Nurcholish Madjid menunjukkan bahwa negara memberi peluang bagi masuknya nilai-nilai Islam ke dalam undang-undang dan peraturan negara. ${ }^{7}$

Wacana yang ketiga, dari hubungan agama dan negara yang tergolong dalam pola hubungan yang bersifat integratif. Pada bagian ini ada tiga variasi wacana yakni: (1) integrasi total dan idiologis, (2) integrasi dalam konsepsi negara pancasila adalah negara Islam, dan (3) integrasi non-idiologis dan non-formal, yang mirip dengan komplementer "nasionalisme Islam" Soekarno.

\footnotetext{
${ }^{5}$ Lihat Muhammad Imaa, Al-Islam wa ushul al-Ahkam li Ali Abd al-Raziq, (Bairut: Tpn,1972), h. 92

${ }^{6}$ Lihat Daliar Noer, Pengantar ke Pemikiran Politik, (Jakarta: Rajawali Press, 1983), h.189-195

${ }^{7}$ Lihat Nurcholish Madjid, Khasanah Intelektual Islam, (Jakarta: Bulan Bintang, 1984), h. 12-13
} 
Dalam hal integrasi total idiologi, gagasannya sudah mengkristal di masa awal kemerdekaan, dengan rumusan konstitusi yang berkekuatan hukum. Yakni dalam konsep yang tertuang dalam dasar negara pancasila, 22 juni 1945, yang dikenal dengan tujuh kata, ${ }^{8}$ yang kemudian melalui kompromi yang alot, akhirnya rumusan tersebut dihilangkan, sebagaimana tertera pada pancasila. Wacana ini kemudian mendapat ruang kembali diperdebatkan pada masa konstituante tentang dasar negara.

Mengenai integrasi dalam konsep negara pancasila sebagai negara yang Islami dapat diterima, dan oleh karena itu pemerintah memiliki keabsahan dalam mengelola zakat, karena zakat yang merupakan urusan keagamaan ditangani oleh negara. Di sini kita melihat hubungan antara agama dengan negara secara integrasi yang demikian kuat melalui negara yang berdasarkan pancasila. Kedudukan pancasila dan Undang-Undang dasar 45 menurut Nurcholish Madjid sama dengan kedudukan dan fungsi dokumen politik pertama dalam sejarah Islam, yaitu piagam Medinah, dan umat pada masa Rasulullah menerima konstitusi Madinah tersebut dalam rangka menyetujui kesepakatan bersama dalam membangun masyarakat politik bersama. ${ }^{9}$

Atas pemikiran tersebut, tampaknya tidak merasa risau ketika pemerintah orde baru memberlakukan Undang-Undang Keormasan (UU No. 8/1985) antara lain menetapkan keharusan mencantumkan pancasila sebagai satu-satunya asas bagi organisasi kemasyarakatan, ia hanya memfilterisasi kehawatiran sebagian umat Islam yang melihat pemberlakuan undang-undang tersebut dapat mereduksi peranan agama Islam yang justru memanfaatkan simbolisme formal agama menjadi kurang dan pada waktu itu Nurcholish Madjid memunculkan idenya pada tahun 1970-an dengan selogan Islam yes, partai Islam no. meskipun tidak ada kewajiban membentuk negara Islam, namun sebagai masyarakat yang bernegara hendaknya dapat membentuk masyarakat yang Islami, karena itu masyarakat Islam adalah masyarakat yang mengikuti perkembangan zaman di bidang politik, ekonomi, dan sosial budaya. ${ }^{10}$

Variasi lain yang bersifat integrasi non-idiologis dan non-formal, yang mirip dengan komplementer "nasionalisme Islam" Soekarno, dapat dilihat melalui sintesis ajaran Islam dan demokrasi yang dapat disimbolkan dengan pemikiran Muhammad Natsir yang menampilkan sintesis yang rasional-logis. Dalam pengertian bahwa prinsip demokrasi adalah menghargai keadilan, persamaan, maka perpaduan Islam dan demokrasi dapat saja menghasilkan partai Islam yang demokratis, atau idiologi Islam yang terbuka dan toleran. Jadi, keberadaan partai Islam seperti Masyumi dan aspirasi suatu negara Islam yang demokratis adalah sebagai representasi dari sintesis

${ }^{8}$ Yakni "Dengan kewajiban menjalangkan syari' at Islam bagi para pemeluknya". Lihat Anwar Haryono, Dibalik Lahirnya Suatu Bangsa dan Negara (Jakarta: UI Press, 1997), h. 28

${ }^{9}$ Lihat Nurcholish Madjid, Cita-cita Poltik Kita, dalam Basco Carillo dan Dasrizal (penyunting), Aspirasi Umat Islam Indonesia, (Jakarta: Lappanas, 1983), h. 11

${ }^{10}$ Lihat Syafii Maarif, Membumikan Islam, (Yogyakarta: Pusta Pelajar, 1995), h. 94 
antara Islam dan negara secara logis-rasional. Termasuk pancasila yang di dalamnya terkandung nilai-nilai ajaran Islam. ${ }^{11}$

Dengan melihat polarisasi hubungan antara agama dan negara yang dikemukakan di atas, maka yang disebutkan terakhir lebih memperlihatkan hubungan yang sangat kuat dan tak terpisahkan, meskipun tidak mengabaikan begitu saja hubungan yang disebutkan kedua yaitu hubungan yang bersifat komplementer.

Atas dasar itulah, argumen fundamental wacana kedua dan ktiga di atas, memperlihatkan ajaran Islam yang prinsipnya masuk ke dalam sila pancasila. Dan oleh karena itu, perjuangan tokoh-tokoh Islam seperti Muhammad Natsir bukan mendirikan negara Islam, tetapi yang penting adalah isinya, yakni kemakmuran dan keadilan bagi rakyat. ${ }^{12}$ Dari sinilah Nurcholish Madjid menolak Islam sebagai idiologi, karena akan merendahkan dan akan mendiskriditkan agama sebagai suatu yang setara dengan idiologi.

Negara Islam bagi beliau merupakan sesuatu yang terjadi secara otomatis, sebagai akibat fakta bahwa orang Indonesia yang mayoritas adalah orang Muslim. Tampaknya bagi Nurcholish Madjid, bila penduduk suatu negara sebagian besar beragama Islam, sudah cukup untuk menyebutnya negara Islam. ${ }^{13}$

Akar perdebatan tentang hubungan Islam dan negara Indonesia, sebagaimana yang dikemukakan di atas, sebenarnya berpusat di sekitar perbedaan paradigma dan grand theory. Perpolitikan "sekuler" yang menjadi trend di Barat (dengan grand theory utama Max Weber yakni gagasan tentang pemisahan agama dari negara) berhadapan dengan "teori emansipatoris" dan pemikiran lain yang bersifat antitesis terhadap perpolitikan sekuler. ${ }^{14}$

Mengingat bahwa para pendiri Republik Indonesia sudah membuat sintesis yang kurang lebih "jalan tengah", tampaknya di masa kini, hubungan Islam dan negara Indonesia tetap dimungkinkan. Indikator "jalan tengah" itu di masa kini adalah, antara lain, adanya output politik bidang perpajakan, yang telah menerima eksistensi pembayaran zakat sebagai bagian atau komponen yang sah dari "pengeluaran untuk pajak". Dan eksistensi bank syariah sebagai bagian dari sistem perbankan nasional. Menurut Nurcholish Madjid, ini adalah bentuk konkret hubungan Islam dengan negara Indonesia yang berdasar pancasila, dan indikator penghargaan sistem politik kita atas apa yang terdahulu disebut sebagai identitas peradaban. ${ }^{15}$

"Jalan tengah" yang disebutkan di atas dapat dielaborasi bahwa jika sekularisasi pemikiran politik dari Barat dalam arti memisahkan agama dan negara secara total, dan proses politik menutup rapat bagi "ruang" agama dan "ruang"

\footnotetext{
${ }^{11}$ Lihat Muhammad Hari Zamharir, Op. Cit., h. 167

${ }^{12}$ Lihat Daliar Noer, Op. Cit., h. 136

${ }^{13}$ Lihat Ibid., h. 203

${ }^{14}$ Lihat Ibid., h. 173

${ }^{15}$ Lihat Ibid., h. 174
} 
politik, sedangkan Bungkarno di Indonesia memisahkan antara agama dan negara secara "lunak", dalam arti proses politik demokratis dapat membuka corak Islam pada negara, maka pada Nurcholish Madjid, ada pembatasan yang fundamental, yakni menolak proses mengidiologikan Islam karena penerimaan: konsep Islam sebagai agama sipil dan penerimaan pluralisme berbasis nilai agama untuk menumbuhkan demokrasi.

Bagi Nurcholish Madjid, “jalan tengah" itu memposisikan agama sebagai ruh negara, atau dengan kata lain bersifat "komplementer", dalam pengertian bersifat saling mengisi atau bersifat saling melengkapi. ${ }^{16}$ Dalam konteks ini, maka pemikiran Ali Abdul Raziq yang membangun sekularisme di dunia Islam, seperti dikemukakan di atas jelas berbeda dengan pemikiran politik Nurcholish Madjid. Pemikiran Nurcholish Madjid berada pada spektrum yang lebih "dekat" dengan poros atau "jalan tengah", sedangkan pemikiran Abdul Raziq cukup jauh dari poros atau jalan tengah.

Dinamika pemikiran di atas, sistem politik Indonesia tidak mengadopsi secara dokmatis asumsi-asumsi dasar pada perpolitikan modern yang menjadi trend di Amerika Utara dan Eropa Barat, tetapi mengadopsi dari nilai-nilai budaya dan agama.

Dalam konteks ini bagi kalangan Neo-Modernis Islam, memandang bahwa demokrasi dipandang sebagai aturan politik yang paling layak, sementara agama diposisikan sebagai wasit moral dalam mengaplikasikan demokrasi.

Hubungan Islam dengan demokrasi, terdapat dua problem, pertama problem filosofis yakni jika klaim agama terhadap pemeluknya sedemikian total, maka akan menggeser ekonomi dan kemerdekaan manusia yang berarti juga menggeser prinsip-prinsip demokrasi. Kedua problem histories sosiologis yakni ketika kenyataannya peran agama tidak jarang digunakan oleh penguasa untuk mendukung kepentingan politiknya. ${ }^{17}$

Menurut Abdurrahman Wahid, bahwa nilai demokrasi ada yang bersifat pokok dan ada yang bersifat derivasi atau lanjutan dari yang pokok. Menurutnya ada tiga nilai pokok demokrasi yaitu, keadilan, kebebasan dan musyawarah. ${ }^{18}$ Keadilan merupakan landasan demokrasi dan peluang bagi semua orang untuk mengatur kehidupannya sesuai dengan keinginannya. Kebebasan yang dimaksudkan adalah kebebasan individual di hadapan kekuasaan negara, atau hak-hak individu sebagai warga negara dan hak kollektif dari masyarakat, sedangkan musyawarah merupakan suatu bentuk cara memelihara kebebasan dan memperjuangkan keadilan lewat jalur permusyawaratan. Dalam Alquran tentang keadilan lihat QS. Al-Maidh

${ }^{16}$ Lihat Nurcholish Madjid, Cendekiawan dan Religiussitas Masyarakat, (Jakarta: Tabloit TEKADParamadina, 1999), h. 139-142

${ }^{17}$ Lihat Tarmizi Thahir, Demokrasi Politik, Budaya dan Ekonomi, (Jakarta: Paramadina, 1994), h. 192

${ }^{18}$ Lihat Abdurrahman Wahid, Pergulatan Negara dan Kebudayaan, Depok, Desentara, 2001, h. 90 
(5): 58 tentang musyawarah QS. Ali Imran (3): 59 dan tentang kebebasan QS. AlAn'am (6): 94.

Gagasan demokrasi pada intinya menganut dasar kesetaraan manusia, sehingga hak-hak individu dapat terjamin kebebasannya. Menurut Nurcholish Madjid, demokrasi sebagai suatu idiologi, tidak hanya karena pertimbanganpertimbangan prinsipil yaitu karena nilai-nilai demokrasi itu dibenarkan dan didukung semangat ajaran Islam, tetapi juga karena fungsinya sebagai aturan permainan politik yang terbuka. ${ }^{19}$

Dalam hubungan ini, Muhammad Hari Zamharir, mengekspresikan aksi politik Nurcholish Madjid di Era Reformasi di Indonesia. Menurutnya, Nurcholish Madjid mengatakan bahwa pemerintah belum reformis. Dalam hal budaya demokrasi secara umum, khususnya lembaga kepresidenan. Beliau melihat bahwa kita masih belum memiliki mentalitas demokrat; kita masih bersandar pada invidu, belum pada sistem dan prosudur demokrasi. "kita harus siap menerima siapa pun yang menang, setan gundul sekalipun". ${ }^{20}$

Pandangan demikian berimplikasi bahwa hubungan Islam dan kenegaraan Indonesia akan lebih bercorak non-idiologis, demikian juga pada pemikiran politik Munawir Sjadzali yaitu menerima sistem kenegaraan pancasila yang demokratis menerapkan keadilan, persamaan. Dan oleh karena itu tidak penting ekspresi politik yang bersifat simbolis atau menjadikan idiologi Islam. ${ }^{21}$

Menyinggung soal perjuangan dan pemikiran tokoh-tokoh yang dikemukakan di atas, secara tersirat menggunakan pendekatan pemikiran substantive. Dalam arti melakukan substansiasi agama ke dalam proses politik dengan menawarkan nilainilai Islam yang ideal berupa etika dan moral sebagai refleksi dari sintesis antara agama dan negara.

Pemikiran yang selalu memformalkan institusi politik seperti istilah Darul Islam (negeri Islam) dan Darul Harb (negeri kafir) atau sebut saja "Negara Islam", bagi Nurcholish Madjid tidaklah tepat, sebab negara Islam yang formalistik itu tidak pernah digunakan, baik oleh Nabi sendiri maupun penggantinya selama berabadabad lamanya, dan jelas sekali bahwa ia muncul di kalangan umat hanya sebagai gejala di zaman modern ini saja. Kemunculannya itu bisa dikaji dalam kaitannya dengan bentuk interaksi umat dengan golongan-golongan lain, dan akan jalas bahwa ide itu, apalagi sebutan formalnya, adalah suatu variable histories sosiologis, bukan esensi agama Islam itu sendiri. ${ }^{22}$

Dalam konteks ini istilah dar al-Islam dan dar al-harb tersebut, lebih melihat pada tataran substantive penyelenggaraan sistem pemerintahan dan proses politik yang

${ }^{19}$ Lihat Nurcholish Madjid, Agama dan Negara dalam Islam: telaah atas Fiqh Siyasa Sunni dalam Budhy Munawar Rahman (ED), Kontekstualisasi Doktrin Islam dalam Sejarah, cet. 2 (Jakarta: Paramadina, 1995), h. 19

${ }^{20}$ Lihat Muhammad Hari Zamhari, Op. Cit., h. 168

${ }^{21}$ Lihat Ibid., h. 203 dan lihat juga Suara Pembaharuan, 13 Mei 1999

${ }^{22}$ Lihat Muhammad Hari Zamharir, Op. Cit., h. 259 
berlangsung, yakni suatu kondisi politik dalam sistem politik yang memberikan jaminan kebebasan menjalankan agama, dengan kekuasaan politik di tangan orang lain.

Paham senada ini juga dikemukakan oleh Marcel A. Boisard, bahwa "suatu negara yang (penguasanya) bukan Muslim, yang tidak mengamcam masyarakat Islam dan mempunyai lembaga-lembaga yang mengajarkan sikap hormat kepada ke adilan yang menjamin kemerdekaan beragama, negara tersebut akan dianggap di luar "kawasan perang" dalam pengertian bukan tergolong dar al-harb dan oleh karena itu hubungan damai yang didasarkan atas kejujuran dan pengakuan timbal balik dapat berkembang". ${ }^{23}$

Lebih lanjut dikatakan bahwa konsep darul Islam vs darul harb bukan berdasarkan wilayah geografisnya, melainkan indikator kualitatif yaitu keadilan, keselamatan dan kemerdekaan beragama untuk umat Islam. ${ }^{24}$

Dalam perspektif ini, baik Nurcholish Madjid maupun A. Boisard, lebih mengutamakan sebuah kondisi kualitatif dalam kehidupan politiknya, bukan penguasanya atau wilayahnya. seandainya pun penguasa beragama Islam tetapi jika output politiknya tergolong pada produk-produk dar al-harb, maka sistem politiknya dapat tergolong dalam "kawasan perang" (darul harb). ${ }^{25}$

Pandangan serupa ini juga yang dianut oleh Muhammad Natsir. Ia lebih mengutamakan sebuah tatanan politik yang berkeadilan, damai dan demokratis. "politik Islam" bagi beliau pada intinya adalah perjuangan untuk diselenggaranya sistem politik yang demokratis dan pluralis, secara khusus diterimanya kemajemukan agama-agama. Jadi di sini secara imflisit ditolak kategori "negeri Islam" vis-à-vis "negeri kafir".

Jadi, menggunakan konsep dan pendekatan "substantive, secara logis dapat dipahami dan diterima. Yakni pentingnya kondisi-kondisi perpolitikan yang secara kultural bersifat damai, adil dan bebas dalam beragama; hubungan antara bangsa cukup terbuka dengan tidak membuat kontradiksi antara masyarakat muslim maupun non muslim. Dengan demikian sistem kenegaraan pancasila yang normative menjunjung tinggi pluralisme, keadilan dan demokratis - jika digunakan konsep dan pendekatan substantive untuk melihat pemikiran politik tokoh-tokoh di atas- dapat diterima oleh masyarakat muslim Indonesia. Karena konsep dan pendekatan substantive demikian ini agaknya lebih dapat dipertanggung jawabkan. Kekuatan penting pendekatan ini adalah dinamikanya dalam melihat segi politik suatu darul-Islam atau darul harb.

Jika kita gunakan khasanah ilmu hubungan internasional, yaitu adanya modelmodel hubungan, yakni kerja sama antar negara, kompetisi antar negara dan konflik,

${ }^{23}$ Lihat Marcel A. Boisard, Humanisme dalam Islam terjemahan HM. Rasjidi (Jakarta: Bulan Bintang, 1980), h. 228-240

${ }^{24}$ Lihat Ibid., h. 139

${ }^{25}$ Lihat Muhammad Hari Zamharir, Op. Cit., h.256 dan lihat pula Marcel A. Boisard, Ibid., h. 235 
serta model campuran, maka model hubungan yang bersifat konflik atau bersifat memusuhi kaum muslimin, mungkin dinamakan darul harb. Jika suatu negeri tidak memiliki perangkat penegak keadilan dan kebebasan beragama, negeri itu disebut darul harb. Jadi indikatornya bukan kafir atau wilayah negara itu, tetapi kualitas sistem politiknya. Cara pandang seperti inilah yang dimiliki pemikiran politik Nurcholish Madjid tokoh-tokoh di atas dalam memandang inti suatu "politik atau negara" menurut citra Islam. ${ }^{26}$

Kata kuncinya pada idealisme pemikiran ini adalah etika politik demokrasi pluralistik, yakni bahwa perpolitikan Indonesia dalam konteks pluralisme dengan mayoritas penduduk muslim hendaknya membudayakan politik demokratis yang berbasis etika dan moralitas agama sebagai perwujudan sintesis antara agama dan negara.

\section{Kesimpulan}

Berdasarkan uraian di atas, maka dapat dikemukakan beberapa kesimpulan yakni: bahwa mengenai agama dan negara berhubungan secara komplementer dan integralistik dalam pengertian bersifat saling mengisi dan saling melengkapi, atau berada pada spektrum yang lebih "dekat" dengan poros tengah atau "jalan tengah". Yakni adanya peluang bagi agama-agama untuk mengisi dimensi etis dari kehidupan bernegara dan moralitas agama, sehingga rumusan "Negara Indonesia bukanlah negara agama bukan pula negara sekuler", tetapi negara yang di dalamnya nilai-nilai agama-agama bisa hidup dan eksis.

Bahwa pandangan dan gagasan tentang demokrasi yang dikedepankan tokohtokoh pemikir politik Islam Indonesia agaknya secara prinsip mengutamakan demokrasi pluralis, dengan konsep demokrasi liberal yang berkembang di Barat. Namun demikian, adopsi nilai dan lembaga demokrasi Barat ini dilakukannya dengan penambahan dan modifikasi, antara lain memasukkan nilai-nilia moral agama. Sehingga dengan demikian demokrasi di Indonesia sesuai dengan budaya bangsa Indonesia.

\section{Daftar Kepustakaan}

Anwar, Syafii, Pemikiran dan Aksi Islam di Indonesia: Sebuah Kajian Politik tentang Cendekiawan Muslim Orde Baru Jakarta: Paramadina, 1995

A. Boisard, Marcel, Humanisme dalam Islam terjemahan HM. Rasjidi Jakarta: Bulan

${ }^{26}$ Lihat Muhammad Hari Zamharir, Op. Cit., h. 258 dan lihat pula Syafii Anwar, Pemikiran dan Aksi Islam di Indonesia: Sebuah Kajian Politik tentang Cendekiawan Muslim Orde Baru (Jakarta: Paramadina, 1995), h. 76, 197-193 dan 203-204 
Bintang, 1980

Haryono, Anwar, Dibalik Lahirnya Suatu Bangsa dan Negara Jakarta: UI Press, 1997 Imaa, Muhammad, Al-Islam wa ushul al-Ahkam li Ali Abd al-Raziq, Bairut: Tpn,1972 Madjid, Nurcholish, Khasanah Intelektual Islam, Jakarta: Bulan Bintang, 1984 Cita-cita Poltik Kita, dalam Basco Carillo dan Dasrizal (penyunting), Aspirasi Umat Islam Indonesia, Jakarta: Lappanas, 1983

Cendekiawan dan Religiussitas Masyarakat, Jakarta: Tabloit TEKADParamadina, 1999

Agama dan Negara dalam Islam: telaah atas Figh Siyasa Sunni dalam Budhy Munawar Rahman (ED), Kontekstualisasi Doktrin Islam dalam Sejarah, cet. 2 Jakarta: Paramadina, 1995

Maarif, Syafii, Membumikan Islam, Yogyakarta: Pusta Pelajar, 1995

Noer, Daliar, Pengantar ke Pemikiran Politik, Jakarta: Rajawali Press, 1983

Suseno, Frans Magnis, Etika Politik Prinsip-prinsip Moral Dasar Kenegaraan Modern Jakarta: Gramedia, 1988

Suara Pembaharuan, 13 Mei 1999

Thahir, Tarmizi, Demokrasi Politik, Budaya dan Ekonomi, Jakarta: Paramadina, 1994

Wahid, Abdurrahman, Pergulatan Negara dan Kebudayaan, Depok, Desentara, 2001 